\title{
India's Quest for Power and Status: A Study of India's Nuclear Policy
}

\author{
Rameez Raja
}

\begin{abstract}
This paper addresses India as an emerging robust nuclear power with its capability of delivering nuclear missiles from all the three major components of nuclear triad. It finds that India's nuclear policy develops with considerable alacrity on its lust for power and was status driven. This paper also points out that India despite a non signatory of NPT and CTBT is declared as a responsible nuclear state and stands on a belief that it will not transit nuclear weapons and technology to other states. India's nuclear doctrine rests on no-first use policy (NFU), second strike capability, sufficient, survivable and operationally prepared nuclear forces, a robust command and control system; effective intelligence and early warning capabilities; comprehensive planning and training for operations in line with strategy; and the requisite primary and alternate chain of command to employ nuclear forces and weapons. The veracity of India's missiles strength is in range to target all areas both of Pakistan and China. India's target of achieving the maximum electricity from nuclear energy is feasible through the NSG waiver. However, this will also help India to increase its nuclear arsenal in the coming years as non signatory of NPT and CTBT. This paper also addresses that the Indo-US civil nuclear deal is the land mark for the India's ambition to move towards achieving the target of becoming mighty nuclear power in Asia. This deal will also validate India's new position in world order based on its recent economic growth; and this deal will symbolize strengthened Indo-US bilateral relations. This paper highlights India's persistence in nuclear relations with other countries to strengthening its ambition to achieve maximum power from nuclear energy.
\end{abstract}

\section{INTRODUCTION}

Indian scientists' and bureaucrats' zeal led to the development of India in a nuclear field and this goal was well planned and shaped by Homi Bhabha with the help of Jawaharlal Nehru after independence. This vision of India's future goals is associated with big science. Big Science meant the institutionalisation of a civilian nuclear energy sector that could also provide the material for a nuclear weapons option. ${ }^{\mathrm{i}}$ Nehru quoted: "Of course if we are compelled to use atomic energy for other purposes, possibly no pious sentiments of any of us will stop the nation from using it that way. But I do hope that our outlook in regard to this atomic energy is going to be a peaceful one....and not one of war and hatred.' (Jawaharlal Nehru, Constituent Assembly, 1948) ${ }^{\mathrm{ii}}$

Nehru linked up the development of atomic energy in the country to "the building of a free and selfreliant India". iii The spread of nuclear weapons to South Asia has long been the subject of intense international concern and India's refusal to accede to the international non-proliferation regime. ${ }^{\text {iv }}$ India's nuclear policy has three interwoven strands that originated in the Nehru-Bhabha years. The first strand is 'diplomatic'. The second strand is labelled as 'scientific/technological activity'. The third strand points to the blending of two above strands at play in nuclear affairs. The first and the second strands speak about an India that has been willing to develop its scientific powers in the nuclear field; and engage the world through its nuclear diplomacy. ${ }^{\mathrm{v}}$ Initially the Indian nuclear policy was based on the commitment to promote development of modern science and technology in India. Nehru had announced that India itself would have nothing to do with the atom bomb and develop atomic energy for peaceful purposes only. ${ }^{\mathrm{vi}}$ Dr. Bhabha approached Sir Dorabji Tata Trust for starting nuclear research in India leading to the establishment of Tata Institute of Fundamental Research (TIFR), Mumbai, which was set up on April 15, 1948. Atomic Energy Commission (AEC) was constituted on August 10, 1948 in order to intensify the studies related to the exploitation of nuclear energy for the benefit of the nation. Exhaustive surveys for rare minerals and uranium deposits were started by the Atomic Minerals Division in India, and on August 18, 1959 Indian Rare Earth Ltd. was established for the chemical processing and recovery of rare earth compounds, and thorium and uranium deposits. A British-designed research reactor APSARA was constructed in 1956; and a second research reactor CIRUS (Canadian-Indian Reactor, US) was provided by Canada in $1960 .^{\text {vii }}$

In July 1968, the Nuclear Non-Proliferation Treaty (NPT) was refused to sign by India on the ground that it was discriminatory or biased in nature. ${ }^{\text {viii }}$ However, India decided to explode its nuclear device calling it 'Peaceful Nuclear Explosion'. ${ }^{\text {ix }}$ The high water-mark of national agreement in India in the nuclear field was the Pokhran explosion of May, 1974 though the Congress government had not consulted even the opposition. ${ }^{\mathrm{X}}$ 
Moving forward India, which along with Pakistan and Israel began to be called "nuclear threshold" nations that had refused to sign the Comprehensive Test Ban Treaty (CTBT) in 1996 as it was also like NPT as discriminatory in nature. ${ }^{\mathrm{xi}}$ On May 11 and 13, 1998, India had detonated five nuclear devices and simultaneously declared that it was a nuclear weapon state, but made no statements about the deployment of its nuclear arsenal ${ }^{\text {xii }}$ In April 2001, India claimed to have entered the select group, called the Big Boys Club, which included the UK, the United States, Russia, France and People's Republic of China. This happened when India successfully launched an experimental satellite atop the GSLV (Geosynchronous Satellite Launch Vehicle). ${ }^{\text {xiii }}$ On July 18, 2005, Indian Prime Minister, Dr. Manmohan Singh visited the United States. The agreement was of India as a major role of power in the coming century - "an anchor of stability in Asia and an engine of global economic growth." More importantly, the agreement is a result of India's strong non-proliferation record despite not being a party to the Nuclear Non-Proliferation Treaty (NPT). Additionally, the deal undoubtedly recognises India's "de-facto" status as a nuclear weapon state ${ }^{\text {xiv }}$ It also promises other potential security benefits, notably enhancing U.S.-Indian counterterrorism cooperation. In these respects, the joint declaration has laid the foundation for promoting the long-term strategic interests of the United States. ${ }^{\mathrm{xv}}$ India has a flourishing and largely indigenous nuclear power programme along with experts to have $14.6 \mathrm{GWe}$ nuclear capacities on line by 2024 and 63 GWe by 2032. It aims to supply $25 \%$ of India's electricity from nuclear power $2050 .{ }^{\text {xvi }}$

\section{POKHRAN}

"India is a nuclear weapons state. This is a reality that cannot be denied. It is not a conferment we seek; nor a status for others to grant... It is India's due, the right of one-sixth of human kind."xvii

India finally exercised its five nuclear tests: three tests were conducted on May 11 and two tests on May 13, 1998 in the Pokhran, Rajasthan. The May 1998 nuclear tests signalled a dramatic shift in India's nuclear posture. It brought India's nuclear capability from the realm of a calm and covert military programme to a publicly known status. ${ }^{\text {xviii }}$ India's decision to go nuclear was status driven and akin to the cases of the United Kingdom, France and the United States. ${ }^{\text {xix }}$ When India proceeded to conduct the series of nuclear tests was not the overall result of Chinese nuclear capabilities but it was the BJP that had been declaring since 1960's that they would turn India into a nuclear power if the Hindu nationalists ever gained the reins of the central government and got success in March 1998 when BJP achieved power. ${ }^{\mathrm{Xx}}$ The leading architect of India's ballistic missile programme and development of nuclear weapons was Dr. A.P.J. Abdul Kalam. ${ }^{\text {xxi }}$ The Indian Prime Minister Atal Bihari Vajpayee publicly celebrated the role of the scientists who designed the weapons and conducted the explosions, raising science to the level of hitherto reserved for those who protect the nation and feed its citizens ${ }^{\text {xxii }}$ and the Bhartiya Janata Party (BJP) enjoyed this technological 'feat'. ${ }^{x i i i}$ These tests were developed as a complex linkage between the greatness of India and the nuclear question. Indians worship science, particularly nuclear science. The flattery of scientists is widespread among the Indian strategic elite ${ }^{\text {xiv }}$ and this elite group or lobby comprises roughly active and retired scientocrats, bureaucrats, diplomats, senior armed forces personnel, as well as politicians, policy-oriented journalists and academics. ${ }^{\mathrm{xx}}$

Vajpayee instantly after the May 1998 tests wrote letter to US President Clinton implying that threat was posed by China with its overt nuclear weapons on its borders. However criticism arose both at home and abroad in justifying China as a threat to India. As a result, the government alter its claim on the China threat and assumed officially that it was actually transfer of nuclear and missile technology from China to Pakistan that assisted India to go nuclear. ${ }^{\text {xxvi }}$ Vajpayee government even publicly declared that India's bomb was not country specific and within a year it was stated that it was not threat specific either. ${ }^{\text {xxvii }}$ According to K. Subrahmanyam, "India's nuclear capability is a stabilizing and balancing factor in a dangerous situation created by the fallout of cold war and proliferation permissiveness of major nuclear weapons powers". ${ }^{\text {xviii }}$

Indeed, in 1998, after India's and Pakistan's nuclear tests, some US analysts stressed the need to allow limited technical support to both countries, to ensure both the security of their nuclear facilities and the nonproliferation of weapons from South Asia. ${ }^{x i x}$ The US failed to detect the tests and was angered by the Indian disinformation programme. The US imposed a number of sanctions on India which were lifted by late 2000 . Other countries especially Japan, Australia and Canada-also put sanctions on India through 2000. China was upset because India implied that it was security threat from China that India went nuclear. Pakistan responded with six nuclear weapons tests on May 28 and 30, 1998 and Islamabad continued its highly publicized missile testing in competition with New Delhi. ${ }^{\mathrm{xx}}$ Some countries for example the US, Canada, Japan imposed economic sanctions against India. A few like Canada and Australia also imposed a ban on ministerial-level talks with India as a sign of their displeasure. Others, especially the US, France, Russia, and the UK sought diplomatic engagement with India based on two parameters: non-proliferation and Indian security. ${ }^{\mathrm{xxxi}}$

Following the indefinite extension of the NPT in 1995, and the decision by the major powers to compel India to become a party to the CTBT, it was clear that policy of nuclear ambiguity was no longer viable. With the Pokhran-II tests in May 1998, India had finally abandoned its ambiguity and declared itself to be a nuclear weapon power. ${ }^{\text {xxxii }}$ The international reactions to the Indian nuclear testing in 1998 had a number of 
characteristics. First, despite the public condemnation by the P-5 (China, France, Russia, the United Kingdom and the United States) and G-8 (Canada, France, Germany, Italy, Japan, Russia, the United Kingdom and the United States) countries, there was a deep division among the P-5/G-8 governments about ways to deal with the new situation. ${ }^{\text {xxxii }}$ India's claim to the status of a nuclear weapon state has been vehemently opposed by the United State and the chances of India getting a Security Council membership have also been diminished by its nuclear tests. ${ }^{\text {xxiv }}$

President Bill Clinton paid a visit to India in March 2000 and the two countries pledged to be partners in peace. For the first time in September 2002, the Bush Administration put India in the category of 'great powers,' and according to C. Raja Mohan, the US 'suggested an Indian role in Asian balance of power and contrasted a positive approach towards India with a more critical one towards, China." ${ }^{\text {xxxv }}$ It is believed that India possesses an arsenal of nuclear weapons and the strength is 50 to 250 however India has not made any official announcements about the size of its nuclear arsenal. ${ }^{\text {xxvi }}$

\section{INDIAN NUCLEAR DOCTRINE AND NO-FIRST-USE POLICY (NFU)}

Vajpayee, in his statement to the Lok Sabha on 27 May, 1998, declared that these nuclear weapons are for self defence, to ensure that India is not subject to nuclear threats or coercion. A week later he told the Indian Parliament that India would follow a policy of 'minimum deterrence' and 'will not be the first to use nuclear weapons'. In an interview in November, 1999, Indian Foreign Minister Jaswant Singh also stated that the 'the principle role of [India's] nuclear weapons is to deter their use by an adversary', and argued that to maintain this 'policy of retaliation only', survivability becomes critical to ensure credibility. The August 1999 Draft Indian Doctrine also embodied the No-First-Use (NFU) principle as part of New Delhi's evolving strategy of 'credible minimum deterrence'. ${ }^{\text {xxxvii }}$ India's nuclear doctrine, in its declaratory form has undergone some changes since it was first announced in August 1999. ${ }^{\text {xxviii }}$ The 1999 doctrine was produced by National Security Advisory Board (NSAB), a group of non-governmental experts that India would not use nuclear weapons first and will not make use of nuclear weapons against non-nuclear countries (Negative Security Assurance or NSA). The doctrine emphasized the need for credible nuclear force that would be able to survive first strike against it as well as the need for strict political control over nuclear forces. ${ }^{\text {xxxix }}$ In January 2003, the government released a brief press statement that revealed some aspects of the 'official' nuclear doctrine. A number of caveats had been added, and some pledges especially that of the NFU and non-use against non-nuclear powers had diluted. There were also details about command and control system. The 1999 doctrine had only talked of a 'punitive' retaliation that would cause 'unacceptable' damage and in 2003 doctrine, the introduction of 'massive' retaliation to a nuclear attack on India and the delusion of both India's NFU pledge as well as the pledge not to attack non-nuclear countries (NSA). In the 2003 version, there is an important qualifier: India will consider the use of nuclear weapons in response to a 'major attack' on India or on Indian forces anywhere with chemical and biological weapons. ${ }^{\mathrm{xl}}$ India's nuclear doctrine calls for sufficient, survivable and operationally prepared nuclear forces, a robust command and control system; effective intelligence and early warning capabilities; comprehensive planning and training for operations in line with strategy; and the requisite primary and alternate chain of command to employ nuclear forces and weapons. ${ }^{\text {xi }}$

\section{INDO-US CIVIL NUCLEAR DEAL}

During the second term of the congress-led government between 2004 and 2009, the US decided to accelerate the process of promoting and consolidating a strategic relationship with India. ${ }^{x l i i}$ An agreement of farreaching consequences was concluded between India and the United States, during Manmohan Singh's visit to the US, on July 18, 2005. The agreement known as Indo-US Nuclear Agreement aimed at separation of India's civil and military facilities and at US resuming civil nuclear cooperation that was suspended after India's first test conducted in 1974. . $^{\text {xiii }}$ The strategic alliance with the United States as stated in the joint statement of July 2005 by the Indian Prime Minister and the US President has four aspects: the political, economic, military and fourthly the nuclear cooperation agreement. ${ }^{\text {xliv }}$ Proponents of the agreement argue that this deal will bring India closer to the United States at a time when the two countries are forging a strategic relationship to pursue common interests in fighting terrorism, spreading democracy, and preventing the domination of Asia by a single power. ${ }^{\text {xlv }}$ Meeting in Washington July 18, Bush and Manmohan Singh agreed to a raft of measures ranging from promoting democracy abroad to increasing bilateral space cooperation. These initiatives followed a June 28 agreement by the two countries' defence ministers to pursue closer military ties, including expanded "collaboration" on missile defences, over the next 10 years. ${ }^{\text {xlvi }}$

Most Indian supporters of this agreement including government officials have given one of the three arguments to support their stand: this deal will give India a source of much needed energy; this deal will validate India's new position in world order based on its recent economic growth; and this deal will symbolize strengthened Indo-US bilateral relations. ${ }^{\text {xlvii }}$ The US President George Bush says the deal was necessary to reflect the two countries improved relations as it strengthens international security by tightening US ties to ally 
India, the world's biggest democracy; and it also ensures that some of India's nuclear industry will undergo international inspection. ${ }^{\text {xlviii }}$ In particular, the deal promises to allow India's access to the international uranium market. New Delhi will be now able to purchase the uranium it needs to fuel those reactors it chooses to put under IAEA safeguards. ${ }^{\text {xlix }}$

As the Indian Prime Minister Dr, Manmohan Singh put it:

“... As a responsible state with advanced nuclear technology, India should acquire the same benefits and advantages as other such states which have advanced nuclear technology. As a result we expect that the resumption of India's nuclear trade and commerce with the U.S. and globally, is an achievable goal, involving the dismantling of the technology denial regimes which have hitherto targeted India.... India is a responsible nuclear power with an impeccable record on nuclear non-proliferation".

Thus with the signing of the Indo-US Civil Nuclear Deal India did find an amount of legitimacy for its nuclear arsenal in the international arena. However it feels strongly that much more is needed in this concept/aspect.

The US-India Civil Nuclear Agreement of 2008 provided the answers to a number of Indian problems at the same time. In spite of its status as a non signatory to the NPT and the CTBT, the NSG waiver and the IAEA go ahead ensured that India would not only retain its nuclear weapons programme, but also preserve its access to international nuclear cooperation. ${ }^{\text {li }}$ On September, 2008, the Nuclear Supplier Group (NSG) removed ban on India's participation in international nuclear trade. ${ }^{\text {lii }}$ On September 6, 2008 India was granted the Waiver at the NSG meeting held in Vienna, Austria. Since the clean waiver in 2008, India has entered into a civil nuclear cooperation agreement with significant number of countries such as the United States, France, Russia, Kazakhstan, and Namibia. Besides, negotiation is going on with other countries such as Australia and Japan. liii

The US Congress on October 1, 2008 gave final approval to an agreement facilitating nuclear cooperation between the United States and India. India has committed itself to sign an additional Protocol (PDF) that allows more instructive IAEA inspections of its civilian nuclear facilities. ${ }^{\text {liv }}$ The US has said that the IndoUS nuclear deal, whose fate now rests with the 45-nation Nuclear Suppliers Group, is currently the principle focus of Washington on the civil nuclear front. ${ }^{\text {lv }}$

The Indian External Affairs Minister, SM Krishna had also said that the MOU that had linked a US firm Westinghouse Electric and the Nuclear Power Company of India was meant to install America's first nuclear reactor in Gujarat, and that this should end all speculations on the implementation of the 2005 Indo-US civil nuclear deal. ${ }^{\text {lvi }}$

\section{INDIA'S CIVIL NUCLEAR COOPERATION WITH OTHER COUNTRIES}

On September 30, 2008, India and France signed a civil nuclear cooperation agreement that includes the provisions on nuclear reactors and nuclear fuel. Russia and India also signed a nuclear cooperation on December 5, 2008. According to a joint declaration issued that day the two countries have agreed to collaborate on constructing additional nuclear power plants for peaceful uses of nuclear energy". Russia is currently constructing two reactors in India at Kudankulam. New Delhi has also concluded other fuel-supply agreements, Nuclear Power Corporation of India Limited (NPCIL) and KazAtomprom, a Kazakh national company, signed a memorandum of understanding January 24, 2009, that includes a provision for Kazakhstan to supply uranium to India. The two countries also signed an agreement on April 16, 2011. This agreement "covers the areas of R\&D, science and technology and various things associated with nuclear energy. Ivii $^{\text {vit }}$

India and Argentina, according to an October 14, 2009, joint statement, agreed to "encourage and support scientific, technical and commercial cooperation for mutual benefit" in the "peaceful uses of nuclear energy". The two countries also signed nuclear cooperation agreements on September 23, 2010. Furthermore, India and the United Kingdom signed a "Civil Nuclear Cooperation Declaration" on February 11, 2010, which will allow for the transfer of nuclear-related technology and equipment to India. Additionally, on July 25, 2011, India and South Korea signed an agreement for "cooperation in the peaceful uses of nuclear energy. lviii Indian Prime Minister, Manmohan Singh and Canadian Prime Minister, Stephen Harper had signed the co-operation agreement on nuclear energy, agriculture, information technology and joint research in the defence field on November 6, 2012. ${ }^{\text {lix }}$ Japan had asked India to sign the Nuclear Non-Proliferation Treaty (NPT) even as the two sides decided to reopen talks on a bilateral civil nuclear agreement. ${ }^{\mathrm{lx}}$

The US Vice President Joe Biden visited India on July 23, 2013 emphatically declared that enhanced economic engagement between India and the US was in their mutual interest as the two countries reaffirmed their commitment to implement the historic civil nuclear deal. ${ }^{\text {xi }}$ India and America agreed to co-operative on civil-nuclear matters but both sides are still waiting for the benefits. ${ }^{1 x i}$ On 25 January, 2015 the United States and India sealed the deal on civilian nuclear energy cooperation agreement after talks between US President, Barack Obama, and Indian Prime Minister, Narendra Modi in New Delhi. During the joint statement, Modi said that the civil nuclear deal was the centre-piece of Indo-US understanding and we are moving towards 
commercial cooperation. The deal was held up because the differences between the two countries on India's nuclear liability law/act that was passed by Indian parliament in 2010 . $^{\text {liii }}$

\section{INDIA AS AN EMERGING STRONG NUCLEAR POWER, MILITARY DOCTRINES AND STRENTH OF MISSILES}

The precursor to military modernization with the introduction of military doctrines, including the Air Force Doctrine (1997), the Draft Nuclear Doctrine (1999), the Army's "Cold Start" Doctrine (2004), and the Maritime Doctrine and Strategy 2004/2007). A typical example is the new navy strategy with an ambition to develop a blue water navy with four major roles, including 1 ,) nuclear deterrence, 2, ) economic and energy security, 3,) forward presence and 4,) naval diplomacy. This sends a clear signal of India's maritime ambitions, built on a blue water navy capable of not only defending the homeland, but of protecting India's wider security interests in the Indian Ocean. .xiv $^{\text {. }}$

India began with its space programme in 1963 by launching of sounding rockets. India launched its first satellite named Aryabhatta during 1975 with USSR help. On July 26, 1983 Integrated Missile Development Programme (IGMDP) for the Research and Development (R\&D) of a comprehensive range of missiles got started. The main agencies responsible for development of this programme were India's Defence Research Development Organization (DRDO) and Ordinance Factories. IGMDP has developed five missiles and their variants: Prithvi, Agni, Akash, Trishul, and Nag. On January 8, 2008 the DRDO has formally announced the successful completion of the IGMDP. ${ }^{\text {lxv }}$ India is close to having nuclear-capable intermediate-range ballistic missiles. This was demonstrated by test firing in 2008 of AGNI III missiles (range of $3000 \mathrm{~km}$ ), which was expected to enter service in 2010/2011. Land-based intercontinental ballistic missiles with a range of more than $5,500 \mathrm{~km}$ are under development. The Indian navy is also developing submarine-launched ballistic missiles, and nuclear-powered attack submarines are entering into service. ${ }^{\text {lxvi }}$ India's Ballistic Missile Defence capability received with the successful launch of an upgraded version of the interceptor missile against an electronically simulated target missile over the Bay of Bengal. India plans to deploy a two-tiered Ballistic Missile Defence system to protect important cities and vital installations from enemy attack. The first phase seeks to destroy incoming enemy missiles of 2,000 km range, while the second phase envisages killing incoming missiles of more than $2,000 \mathrm{~km}$. ${ }^{\text {lxvii }}$ India has also expressed an interest in setting up satellite-based early warnings.... ${ }^{\text {Ixviii }}$ The following table provides some useful details of Indian missiles.

\begin{tabular}{|c|c|c|c|c|}
\hline Designation & Class & Payload & Range & Status \\
\hline Agni-1 & SRBM & $\begin{array}{l}\text { Single } \\
\text { warhead, } 2,000 \\
\mathrm{~kg}\end{array}$ & $700-1,200 \mathrm{~km}$ & Operational \\
\hline Agni-2 & IRBM & $\begin{array}{l}\text { Single } \\
\text { warhead, } 1,000 \\
\mathrm{~kg}\end{array}$ & $\begin{array}{l}2,000-3,500 \\
\mathrm{~km}\end{array}$ & Operational \\
\hline Agni-3 & IRBM & Single warhead & $\begin{array}{l}3,500-5,000 \\
\mathrm{~km}\end{array}$ & Development \\
\hline Agni-4 & IRBM & $\begin{array}{l}\text { Single } \\
\text { warhead, } 800 \\
\text { kg }\end{array}$ & $3,500 \mathrm{~km}$ & Development \\
\hline Agni-5 & ICBM & & $\begin{array}{l}5,000-8,000 \\
\mathrm{~km}\end{array}$ & Development \\
\hline $\begin{array}{l}\text { Agni } \\
\text { (technical } \\
\text { demonstrator) }\end{array}$ & MRBM & $\begin{array}{l}\text { Single } \\
\text { warhead, } 1,000 \\
\mathrm{~kg}\end{array}$ & $700-1,200 \mathrm{~km}$ & Terminated \\
\hline Dhanush & SRBM & $\begin{array}{l}\text { Single } \\
\text { Warhead, 500- } \\
1,000 \mathrm{~kg}\end{array}$ & $250-350 \mathrm{~km}$ & Operational \\
\hline Prahaar & SRBM & $200 \mathrm{~kg}$ & $150 \mathrm{~kg}$ & Development \\
\hline Privthi 3 & SRBM & $\begin{array}{l}\text { Single } \\
\text { warhead, } 500- \\
1,000 \mathrm{~kg}\end{array}$ & $300-350 \mathrm{~km}$ & Development \\
\hline $\begin{array}{lr}\text { Prithvi } & \text { SS- } \\
150 / & -250 /- \\
350 & \\
\end{array}$ & SRBM & $\begin{array}{l}\text { Single } \\
\text { warhead, } 1,000 \\
\mathrm{~kg}\end{array}$ & $150 \mathrm{~km}$ & Operational \\
\hline Sagarika & SLBM & Single warhead & $700 \mathrm{~km}$ & Developed \\
\hline
\end{tabular}


India's Quest for Power and Status: A Study of India's Nuclear Policy

\begin{tabular}{|l|l|l|l|l|}
\hline (K-15) & & & & \\
\hline Shaurya & SRBM & $\begin{array}{l}\text { Single } \\
\text { warhead, 500- } \\
800 \mathrm{~kg}\end{array}$ & $700 \mathrm{~km}$ & Development \\
\hline Surya-1/-2 & ICBM & $2,500 \mathrm{~kg}$ & $\begin{array}{l}8,000-12,000 \\
\mathrm{~km}\end{array}$ & \\
\hline
\end{tabular}

Table 1: Source: Missile Threat Indian Missiles ${ }^{\text {lxix }}$

Following map indicates probable ranges of different versions of Agni missiles:

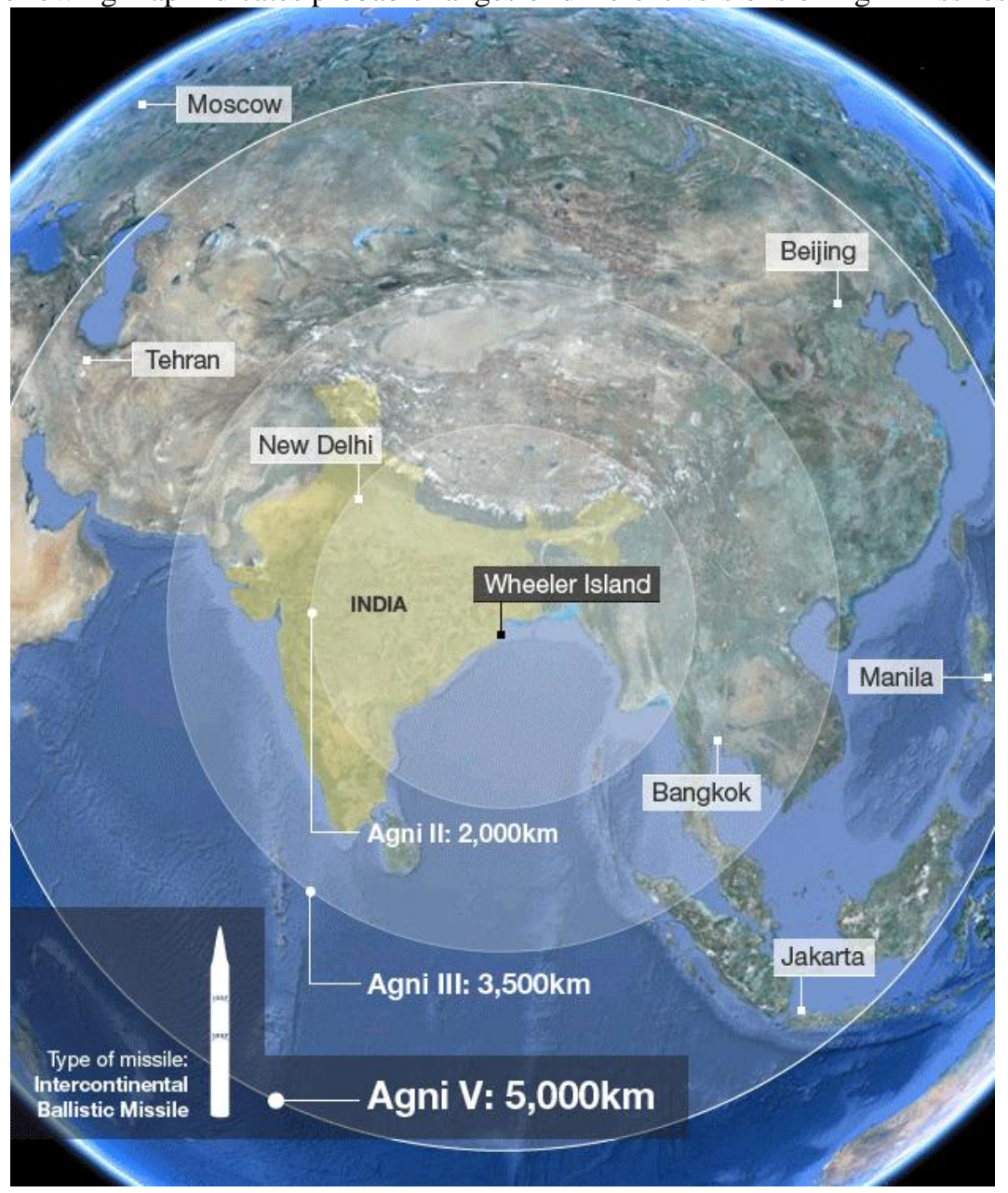

Figure 1: Agni missile range on map, Source: Defence Research Development Organization (DRDO). ${ }^{\text {lxx }}$

\section{VII.}

CONCLUSION

India's nuclear development had been influenced by multiple factors. The Bhabha-Nehru period that moved to use nuclear energy for industrial growth and economic prosperity, to achieve technological and scientific self-sufficiency, the aspiration to transform India into a 'great state'. India thought of using nuclear energy for military purposes after 1960's and an impetus provided by the Chinese nuclear test in 1964 that Indira Gandhi, Prime Minister of India adopted a 'nuclear option' strategy which eventually culminated into the India's first nuclear test in 1974 (Pokhran I) code named 'Smiling Buddha'. India's rejection of NPT and CTBT as discriminatory in nature prompted it go overtly nuclear. India's nuclear development changed from covert to overt in 1998 and nuclear tests were status driven rather than threat driven. It was in the minds of Indian scientists and bureaucrats to develop India as a nuclear power and was dreaming of becoming big science after Independence. India pursued a policy of nuclear ambiguity before 1998. India conducted five nuclear tests in May 1998 and stands on no-first-use policy (NFU) and nuclear deterrent. India's nuclear strength of warheads is low as compared to China and Pakistan, but the civil nuclear agreement between India and US with the principle change, the separation of its civilian and military nuclear facilities, is of largely symbolic importance and mainly 
facilities civil nuclear energy cooperation rather than increasing protection and control. The agreement strengthens the non-proliferation regime through symbolic acceptance of the NSG, Missile Technology Control Regime (MTCR), and the IAEA safeguards. India stands on responsible nuclear state despite a non signatory of NPT and CTBT. India has an ambitious plan to produce electricity through nuclear energy. The permission of fuel to Indian nuclear reactors through the NSG waiver, this will help India to achieve its goal of emerging strong nuclear power in next 10-15 years. India's peaceful nuclear relations with US, Canada, Russia, France, Argentina, Japan, and South Korea will help India to achieve its target to produce more electricity from nuclear energy. India's relation particularly with US by civil nuclear deal is the land mark for India's ambition to move towards commercial cooperation, and for fighting terrorism, spreading democracy, and preventing the domination of Asia by a single power. This deal will validate India's new position in world order and this deal will symbolize strengthened Indo-US bilateral relations. India's nuclear triad with three major components-the strategic bombers, Inter Continental Ballistic Missiles (ICBMs) and Submarine Launched Ballistic Missiles (SLBMs) for the purpose of delivering nuclear weapons also highlights India as an emerging strong nuclear power.

References

${ }^{\mathrm{i}}$ Vanaik, A., 2015. After The Bomb: Reflections on India's Nuclear Journey. New Delhi: Orient Blackswan. p. 25.

ii Abraham, I., 1998. The Making of the Indian Bomb: Science, Secrecy and the Postcolonial State. New Delhi: Orient Longman. p. 49.

iii Karnad, B., 2005. Nuclear Weapons and National Security. New Delhi: Macmillan India Ltd. p. 179.

iv Ganguly, S. \& Kapur, S. P., 2010. India, Pakistan, and the Bomb: Debating Nuclear Stability in South Asia. New Delhi: Penguin. p. 23.

${ }^{v}$ Kapur, A., 2001. Pokhran and Beyond: India's Nuclear Behaviour. New Delhi: Oxford University Press. pp. 45-47.

${ }^{v i}$ Poulose, T. T., 1970. Perspectives of India's Nuclear Policy. New Delhi: Young Asia. p. 54.

vii Cohen, S. P., 2001. India: Emerging Power. New Delhi: Oxford University Press. p. 158.

viii Jangir, D. S., 2012. Indo-US NUclear Deal and 123 Agreements. International Journal of Scientific and Research Publications. October. 2(10). p. 1.

${ }^{\text {ix }}$ Overholt, William. H., 1977. Asia's Nuclear Future. Boulder Colorado: Westview Press. p. 174.

${ }^{\mathrm{x}}$ Poulose, T. T., 1970. Perspectives of India's Nuclear Policy. New Delhi: Young Asia. p. 63

${ }^{x i}$ Khana, V. N., 2009. Foreign Policy of India. New Delhi: Vikas Publishing House. p.198.

${ }^{x i i}$ Cohen, S. P., 2001. India: Emerging Power. p. 178.

xiii Khana, V. N., 2009. Foreign Policy of India. p. 209.

${ }^{x i v}$ Rajagolpan, R. P., 2008. Indo-US Nuclear Deal: Implications for India and the Global NRegime, Institute of Peace and Conflict Studies. December. No. 62. pp. 1-2.

${ }^{\mathrm{xv}}$ Fred, M., Bengelsdorf, H. \& Scheinman, L., 2005. The U.S.-India Nuclear Deal: Taking Stock, Arms Control Today, October. Volume 35. p. 6.

xvi Anon., 2015. Nuclear Power in India. [Online] Available at: http://www.worldnuclear.org/info/Country-Profiles/Countries-G-N/India/

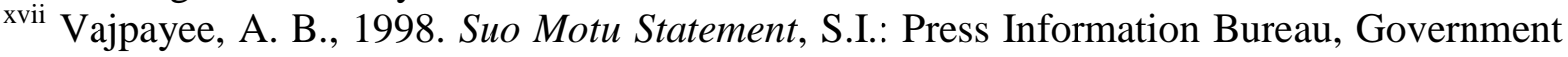
of India.

xviii Yadav, R. S. \& Suresh, D., 2009. India's Foreign Policy, New Delhi: Shipra Publication House. p. 179.

${ }^{x i x}$ Vanaik, A. 2015. After The Bomb: Reflections on India's Nuclear Journey. p. 147.

${ }^{\mathrm{xx}}$ Thomas, R. G. C. \& Gupta, A., 2000. Introduction, in Raju, G. C. Thomas \& Amit Gupta, (Ed.). Indian National Security. New Delhi: Vistaar Publication. p. 3. 
${ }^{x x i}$ Sen, A., 2001. India and the Bomb, in Smitu Kothari \& Zia Mian, (Ed.). Out of the Nuclear Shadow. New Delhi: Lokayan and Rainbow Publishers Ltd. p. 119.

${ }^{x x i i}$ Ramana, M. V., 2013. Scientists and India's Nuclear Bomb. in Pervez Hoodbhoy, (Ed.). Confronting the Bomb: Pakistani and Indian Scientists Speak Out. Karachi: Oxford University Press. p. 23.

xxiii Bidwai, P. \& Vanaik, A., 2001. South Asia on a Short Fuse. New Delhi: Oxford University Press. p. 49.

xxiv Cohen, S. P., 2000. Why Do India "Go Nuclear"?, in Raju, G. C. Thomas and Amit Gupta, (Ed.). India's Nuclear Security. New Delhi: Vistaar Publication. pp. 17-18.

${ }^{\mathrm{xxv}}$ Vanaik, A., 2015). After The Bomb: Reflections on India's Nuclear Journey. p. 23.

${ }^{x x v i}$ Maria, I. \& Shinichi, O., 2003. The Nuclear Policy of India and Pakistan. NIDS Security Reports. March. No. 4. p. 63. .

${ }^{x x v i i}$ Vanaik, A., 2015. After The Bomb: Reflections on India's Nuclear Journey. p. 149.

xxviii Kapur, S. P., 2008. Dangerous Deterrent: Nuclear Weapons proliferation and Conflict in South Asia. New Delhi: Oxford University Press. p. 8.

${ }^{x x i x}$ Gahlaut, S. \& Bertsch, G. K., 2004. The War on Terror and the Nonproliferation Regime, Orbis, Summer. 48, No. 3. p. 492.

${ }^{\mathrm{xxx}}$ Cohen, S. P., 2001. India: Emerging Power. pp. 178-179.

${ }^{x x x i}$ Kapur, A., 2001. Pokhran and Beyond: India's Nuclear Behaviour. pp. 220-221.

xxxii Chari, P. R., ed. 2009. Indo-US Nuclear Deal Seeking Synergy in Bilateralism. New Delhi: Routledge, Taylor and Francis Group. p. 174.

xxxiii Kapur, A., 2001. Pokhran and Beyond: India's Nuclear Behaviour. pp. 220-222.

${ }^{x x x i v}$ Shukla, V., 2005. India's Foreign Policy in the New Millennium: The Role of Power. New Delhi: Atlantic Publishers and Distribution. p. 142.

${ }^{x x x v}$ Khana, V. N., 2007. Foreign Policy of India. pp. 278-281.

${ }^{x x x v i}$ Pandey, D. A., 2009. India's Defensive and Offensive Capability, Scholar's Voice: A New Way of Thinking. January. Vol. 1, No. 1. p. 144.

xxxvii Hussian, R., 2007. Deterrence and Nuclear Use: Doctrines in South Asia, in E. Sridharan, ed. The India-Pakistan Nuclear Relationship: Theories of Deterrence and International Relations. New Delhi: Routledge. p. 157.

xxxviii Ahmad, A., 2014. India's Doctrine Puzzle: Limiting War in South Asia. New Delhi: Routledge. p. 61.

xxxix Rajagopalan, R., 2010. India's Nuclear Policy, in: NIDS National Symposium on Security Affairs, Major Powers' nuclear policies and International Order in the 21st century, Tokyo. [Online] Available at: http://www.nids.go.jp/english/event/symposium/e2009.html ${ }^{\mathrm{xl}}$ Rajagopalan, R., 2010. India's Nuclear Policy.

${ }^{x l i}$ Lele, A. and Bhardwaj, P., 2013. India's Nuclear Triad: A Net Assignment. Indian Institute for Defence Studies and Analysis. April. p. 13.

xlii Vanaik, A., 2015. After The Bomb: Reflections on India's Nuclear Journey. p. 14.

xliii Khana, V. N., 2007. Foreign Policy of India. p. 283.

${ }^{x l i v}$ Jangir, D. S. K., 2012. Indo-US Nuclear Deal and 123 Agreements, International Journal of Scientific and Research Publications. October. Volume 2, Issue 10. p. 1.

xlv Bajoria, J. \& Pan, E., 2010. The U.S.-India Nuclear Deal. [Online] Available at: http://www.cfr.org/india/us-india-nucleardeal/p9663

xlvi Boese, W., 2005. Bush Promises India Nuclear Cooperation. Arms Control Today. September. 35, p. 23.

xlvii Patel, C., 2015). Indo-US Nuclear Deal. [Online] Available at:

http://www.yidream.org/indousnuke_oped_patel_shtml 
xlviii Reuters, 2006. What Does Indo-US Nuclear Deal Mean?. [Online]. Available at: http://www.expressindia.indiaexpresss.com/news/fullstory.php?newsid=71625

xlix Zia, M. \& Ramana, M. V., 2006. Wrong Ends, Means and Needs: Behind the U.S. Nuclear Deal with India. Arms Control Today. Vol. 36, No. 1. p. 3.

${ }^{1}$ Indian Prime Minister, Dr Manmohan Singh, said in 2005. See also Bruneau, R. 2006. Engaging a Nuclear India: Punishment, Reward, and the Politics of Non-Proliferation. pp. 27-28. [Online] Available at: https://www.princeton.edu/jpia/past-issues-1/2006/2.pdf [Accessed 4 January 2016].

li Rajagopalan, R. 2010. India's Nuclear Policy.

lii Charnysh, V., 2009. India's Nuclear Program. p. 3. [Online] Available at: http://www.charnysh.net/Documents/charnysh_india_analysis.pdf.

liii Hussain, M. S. \& Begum, J., 2012. India's Policy of Civil Nuclear Cooperation. [Online] Available at: http://www.thewashingtonreview.org/india-nuclear-cooperation

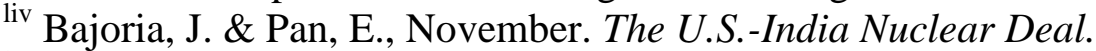

${ }^{1 v}$ Anon., 2008. India nuke deal prime focus of US nuclear policy: Rice. [Online] Available at: http://www.timesofIndia.indiatimes.com/world/us/india-nuke-deal-prime-focus-of-usnuclear-policy-Rice/articleshow/3405150.cms

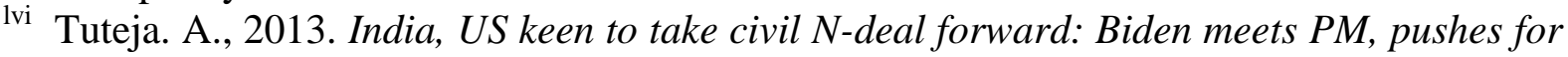
stronger economic ties. [Online] Available at: http://www.tribuneindia.com/2013/20130724/main1.htm [Accessed 24 February 2016].

${ }_{\text {lvii }}$ Kerr, P. K., 2012. US Nuclear Cooperation with India: Issues for Congress. pp. 3-5. [Online] Available at: http://www.fas.org/sgp/crs/nuke/RL33016.pdf

lviii Kerr, P. K., 2012. US Nuclear Cooperation with India: Issues for Congres. p. 8.

${ }^{\text {lix }}$ Meyer, P., 2011. India and the Meltdown of Canada's Nuclear Non-Proliferation Policy.

[Online] Available

at: http://www.thestar.com/opinion/editorialopinion/2011/11/15/india_and_the_meltdow n-of_Canadas_Nuclear-nonproliferationpolicy.html

lx Diksht, S., 2012. Sign Nuclear Non-Proliferation Treaty, Japan Tells India. [Online] Available at: http://www.thehindu.com/news/national/sign-nuclear-nonproliferation-treatyjapan-tells-india/article337154.ece

${ }_{\text {lxi }}$ The Tribune. 2013. Jalander.

lxii Anon., 2014. India ratifies, at last, a nuclear deal with IAEA. [Online] Available at: http://www.economist.com/news/asia/21605961-india-ratifies-last-nuclear-deal-iaea-lateaddition [Accessed 24 February 2016].

lxiii Pandey, K., 2015. Modi, Obama seal nuclear agreement deal. [Online] Available at: http://www.downtoearth.org.in/content/modi-obama-seal-nuclear-agreement-deal [Accessed 20 January 2016].

lxiv Anon., n.d. India and the future global order. p. 11 [Online] Available at: https://www.regjeringen.no/globalassets/.../india studie_ssek_301109.pdf [Accessed 10 February 2016].

${ }^{1 x v}$ Lele, A. and Bhardwaj, P., 2013. India's Nuclear Triad:A Net Assignment. Indian Institute for Defence Studies and Analysis. p. 17.

${ }_{\text {lxvi }}$ Anon., India and the future global order. p. 12.

lxvii Mallikarjun, Y., 2015. Upgraded interceptor missile successfully hits virtual target. [Online] Available at: http://www.thehindu.com/news/cities/Hyderabad/upgradedinterceptor-missile-successfully-engages-electronically-simulated-targetmissile/article7905298.ece [Accessed 24 February 2016]. 
Ixviii Ramana, M.V. Rajaraman, R. \& Mian, Z., 2004. Nuclear Early warnings in South Asia: Problems and Issues. Economic and Political Weekly. January. Vol. 39, No. 3, p. 281.

lxix Marshall, G. C., 2012. Missile Threat. [Online] Available at: http://missilethreat.com/missiles-of-the-world/. [Accessed 2016 February 24].

${ }^{1 x x}$ Anon., n.d. Ranges of missiles Agni II, III \& IV. [Online] Available at: https://www.google.co.in/search?q=agni+missiles+range+on+map+DRDO\&espv= $2 \&$ biw $=1366 \&$ bih $=677 \&$ tbm $=i$ sch $\&$ tbo $=u \&$ source $=$ univ $\& s a=X \&$ ei $=9$ Ugm Vc2jCI63uATkn YKICQ\&ved=0CBwQsAQ\#imgrc=crfUUAjYEHO_TM\%253A\%3BiBFyv9miyrDovM\%3B http\%253A\%252F\%252Fnews.bbcimg.co.uk\%252Fmedia\%252Fimages\%252F59698000\%2 52Fgif\%252F_59698869_agni_v_missile_range.gif\%3Bhttp\%253A\%252F\%252Fforums.bis tudio.com\%252Fshowthread.php\%253F133595- [Accessed 24 February 2016]. 